\title{
FACTORS, RESOURCES AND MOTIVATORS INNOVATIVE OF SMALL AND MEDIUM-SIZED ENTERPRISES IN THE KUJAWSKO-POMORSKIE PROVINCE
}

\begin{abstract}
A b stract: Innovation, and therefore the ability to implement innovations in the current era becomes, or at least should be an attribute of each company. However, the same innovation should not be seen merely as a radical change of international importance. Sometimes, even the smallest adjustments in the way of management or production method prove to be extremely important in achieving competitive advantage in the market. Environment in which businesses operate forces them to be innovative, no matter what their activities are provided also part size. The purpose of this article is to present selected aspects of the innovation sector of small and medium-sized companies of the Kujawsko-Pomorskie.
\end{abstract}

Ke y w ord s: innovation; research and development; small and medium-sized enterprises.

Klas y fikacja JE L: L21.

* Adres do korespondencji: Dorota Grego-Planer, Uniwersytet Mikołaja Kopernika w Toruniu, Wydział Nauk Ekonomicznych i Zarządzania, Katedra Zarządzania Przedsiębiorstwem, ul. Gagarina 13a, 87-100 Toruń, e-mail: dgp@econ.umk.pl; Katarzyna Liczmańska, Uniwersytet Mikołaja Kopernika w Toruniu, Wydział Nauk Ekonomicznych i Zarządzania, Katedra Zarządzania Przedsiębiorstwem, ul. Gagarina 13a, 87-100 Toruń, e-mail:kliczmanska@econ.umk.pl. 


\section{WSTĘP}

Contemporary economic reality is characterized by ever increasing dynamics of change, great uncertainty and strong competition among its participants. Any company operating in this reality and therefore in their surroundings, remains with him in continual interaction, grappling with the same difficult conditions have before it puts these surroundings. Those organizations that want to survive and to occupy leading market positions, must respond to the many changes occurring in the environment. This is reflected in the number and types of new innovations within the company. Glabiszewski writes: ,the need to adapt to changes in the environment, and even their predictions and overtaking... is nowadays a serious challenge for managers, whose work has become increasingly complex and difficult, and above all more responsible. It is therefore increasingly important role played by these methods used in the management, resources disposed of or used instruments that must be more creative and original, and so innovative in nature than before" [Glabiszewski, 2008, p. 95-96]. Thus the necessity for the introduction of continuous change affects not only the biggest players, but every single company, regardless of its size or site of action. This article was devoted to a very innovative activities undertaken by small and medium-sized enterprises. It is up to them, because in today's era very much depends and will depend on the success of the Polish economy. Fragment presented in the publication of research results innovation concerns the SME sector in kujawsko-pomorskie. This sector in the region at the end of 2012 counted up to 187996 entities. The dominant group were micro-enterprises, employing 9 and less people. Among them 95,2\% of companies all over the SME sector in kujawsko-pomorskie. Small businesses employing from 10 to 49 employees was 7094, or 3,8\%. Medium-sized enterprises (employing between 50 and 249), which was 1620 represent approximately $0,8 \%$ of the group. On a side note, you can add that 218 operators in kujawsko-pomorskie is large enterprises, and therefore the employment of over 250 employees ${ }^{1}$. The above figures are therefore only a confirmation of how important the sector plays in the local economy.

1 Zmiany strukturalne grup podmiotów gospodarki narodowej $w$ rejestrze Regon w województwie kujawsko-pomorskim w latach 2011-2012, Urząd Statystyczny w Bydgoszczy, Bydgoszcz 2013, s. 59. 


\section{INNOVATION AS A SOURCE OF COMPETITIVENESS OF ENTERPRISES}

The phenomenon of globalization associated largely with the concept of an open market economy forces currently possess certain characteristics company. One of these essential traits of competitiveness, which is considered to be ,the company's ability to efficiently achieve its goals for a competitive market arena [Stankiewicz, 2002, p. 36]". Each company has the ability, but only when they can effectively create and commercialize innovation. Thus, writes M. Haffer, ,the number, frequency and depth introduced by the company successful innovation determines its level of competitiveness" [Haffer, 2008, s.75]. We can not become a market leader, the company reaching a competitive advantage without changes or not using the latest technology. So what is the same innovation? Innovation is defined most often ,the ability to create and implement changes in various spheres of socio-economic life. This occurs mainly in how to meet the needs - by improving existing and introducing new products and services, as well as ways of human activities in the implementation processes of manufacturing and services aimed at obtaining manufactured products and enabling the production of new goods - which requires changes in organizational structures and used technique as used tools and technological methods" [Bogdanienko, 2004 , p. 21]. Your best bet, however, innovation, following the foreign authors [see Link Siegel, 2007, p. 3; Freeman, 2008, p. 9], can be defined as the ability to create innovation.

An extremely important role of innovation among the sources of competitive advantage he saw $\mathrm{M}$. Porter, who claimed that companies achieve a competitive advantage thanks to conduct innovative activities. The abovementioned author noted that companies strive for innovation in its broadest sense, taking into account not only new technologies, but also new ways of dealing [see Porter, 2001].

Interesting are also the study of H. Simon, which show that the basis for the activities of German small and medium sized businesses that have gained position in the global market leaders in sales of specialized products was just innovation strategy. Professor Simon calls these companies mysterious (or hidden) champions who have achieved positions of world leaders through the use of pioneering technology [see Simon, Dietl, 2009]. The situation is similar on the Polish market, mysterious masters. Research conducted by one of the authors of this publication over the Polish hidden 
leaders have also confirmed that a significant part of the market did not exist before they were created by these innovators [more on this subject: Grego-Planner, 2014 (1), pp. 161-171; Grego-Planner, 2014 (2), pp. 87-103].

K. Poznańska in her article „Innovation as a source of competitive advantage of Polish enterprises" cites a whole range of concepts that lead to the conclusion that innovation can be taken as a basis for building competitive advantage [see Poznańska, 2003]. You can not only expert on the subject, which is the subject of this article, but also every single company operating in the market today would agree with the above statement. Thus, both large corporations as well as small and medium-sized companies, of which increasingly depends on the success of the economy of each country are aware that being innovative is now even compulsion, subject to the survival and development of any organization.

\section{METHODOLOGY AND CHARACTERISTICS OF THE COMPANIES INVESTIGATED}

Empirical studies that portion of the results is analyzed here were carried out in the framework of the research project "Identifying the degree of innovation companies of the Kujawsko-Pomorskie". The project was completed at the Department of Business Management at the Faculty of Economics and Management, Nicolaus Copernicus University in Toruń, from February to June 2014. The study was conducted in 66 companies located in kujawsko-pomorskie.

The test requires the use of the original measurement methods. In order to collect data from primary sources directly used a questionnaire as a method of measurement, in which the measurement instrument was a questionnaire. Respondents in the context of questions were asked on the characteristics of the number of employees. Almost $41 \%$ of them are micro-entrepreneurs employing from 0 to 9 employees, $35 \%$ are small enterprises with number of employees ranging from 10 to 49 employees, $18 \%$ are medium-sized companies, which employ 50 to 249 people, while $6 \%$ are large enterprises with more than 250 employees. The results are presented in Chart 1. 


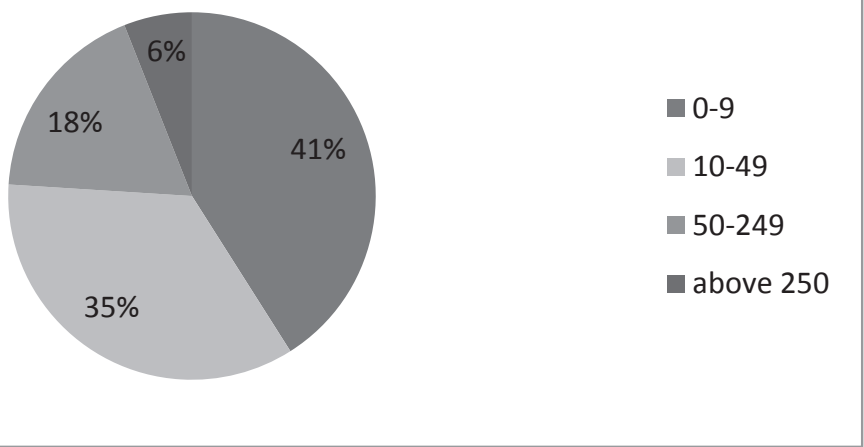

Chart 1. The size of the surveyed enterprises in terms of number of employees Source: own study based on the results of research in enterprise

Considering the turn of the respondents in terms of the legal form of their operation, the vast majority were natural persons conducting economic activity $-71 \%$ of respondents. Almost $23 \%$ of the surveyed enterprises are limited liability companies, partnerships 3\%, 3\% of joint stock companies. Detailed data is shown in Chart 2.

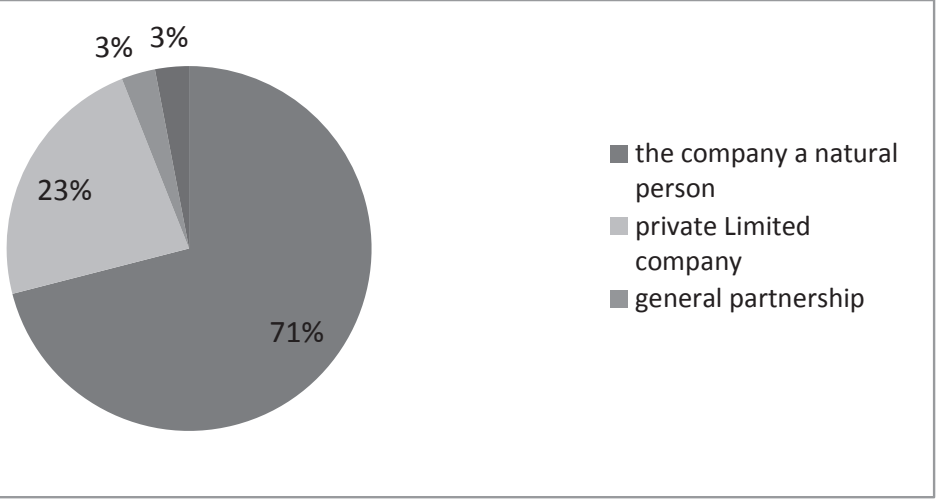

Chart 2. Legal form of activity of the surveyed enterprises

Source: own study based on the results of research in enterprise.

Looking at respondents through the prism of what they do, or rather what products dominate sales in their answers were as follows:

- $41 \%$ of respondents provides services;

- almost 32\% offers consumer products; 
- more than $6 \%$ of respondents offers products consumer durables;

- less than $1,5 \%$ of investment products;

- $10,5 \%$ of the products of a supply-cooperative;

- 9\% customized products manufactured to special order customers.

Replies illustrated in Chart 3.

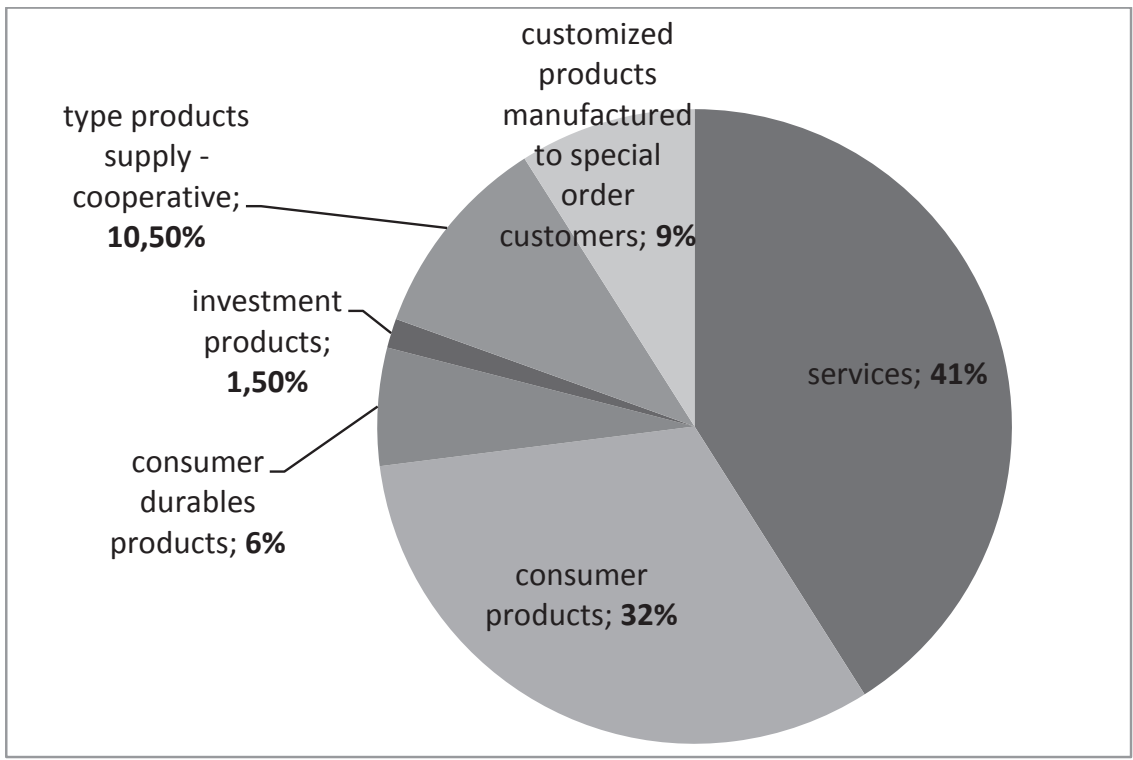

Chart 3. The dominant products in the sales of surveyed enterprises

Source: own study based on the results of research in enterprise.

Another question that answers respondents gave was the year the company was founded. The smallest firms established in the years 1900-1950only $4,5 \%$, slightly more because $12,1 \%$ in $1951-1980,47 \%$ arose from 1981 to 2000 , while $36 \%$ after 2000 (see Chart 4). 


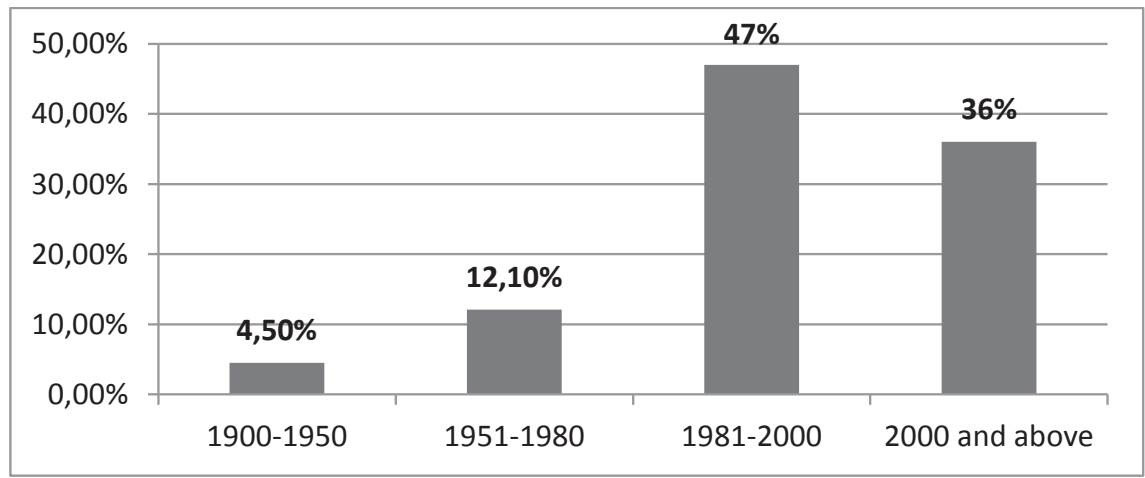

Chart 4. Year of establishment of the surveyed companies

Source: own study based on the results of research in enterprise.

\section{SELECTED OPERATING CONDITIONS OF INNOVATIVE SMALL AND MEDIUM ENTERPRISES IN KUJAWSKO-POMORSKIE}

Analyzing the innovative activity of the surveyed enterprises in the first place should pay attention to what factors the respondents believe have the greatest influence on her. What really affects the fact that the company he wants and intends to implement this innovation. The surveyed firms in their replies could indicate some of these factors, hence the sum of the percentages exceeds 100 .

For almost $73 \%$ of respondents are extremely important competent and creative staff. It is their commitment and skills depends in most of the surveyed enterprises degree of innovation of their company. Employees become a source of innovation implemented. Very important driver to make changes to become competitive. For more than $68 \%$, this factor has the greatest impact on their company's innovation. Can you beat the competition by staying behind? Any company that wants to survive in the market and achieve success just has to be an innovator. Modern production technologies emerging on the market is another factor stimulating innovation, $53 \%$ of respondents. More than half of small and medium-sized enterprises in kujawsko-pomorskie occasions and uses advanced technologies that allow to reduce costs and production on a larger scale. For every third respondent innovation forces the same market demand. The growing 
expectations of our customers and their increasing need prompt companies to exit these needs, which involves the introduction of many changes in the business. Last fairly important factor affecting the innovation of respondents are financial stability of the company. Answered just over $27 \%$ of respondents. Details are presented in Chart 5.

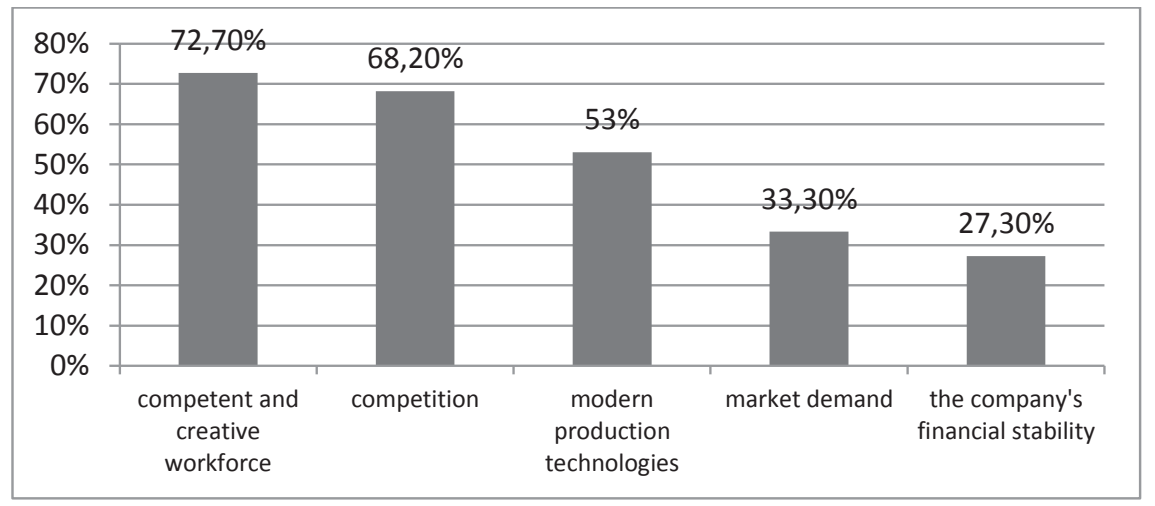

Chart 5. Factors influencing the innovation of the surveyed companies

Source: own study based on the results of research in enterprise.

The surveyed companies were also questions about the sources of innovation. Here, $72 \%$ of respondents indicated that they cooperate in this regard with other companies. More than half of the companies replied that their innovation is own initiative of individual employees. Unfortunately, a lot less respondents indicated that they source their innovations are the work of its dedicated research and development department (18.2\%), as well as the purchase of patents or licenses (18.2\%). The data shows a graph 6 (sum of the percentages exceeds 100 because respondents could indicate more than one response). 


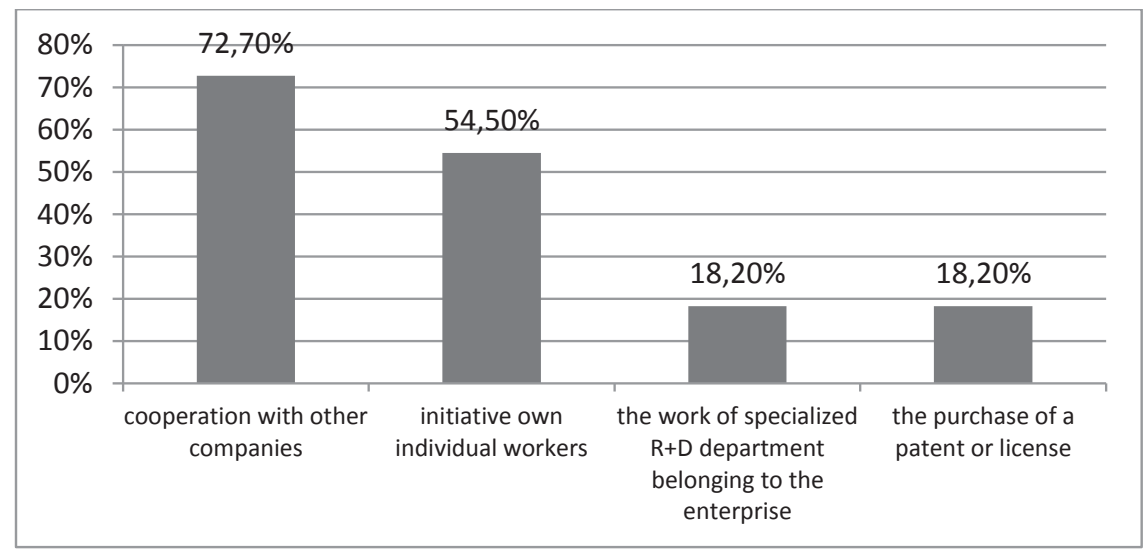

Chart 6. Sources of innovation by the surveyed companies

Source: own study based on the results of research in enterprise.

An interesting fact is that in response to another question, respondents determines whether the company cooperates with other organizations in the field of research and development. Here, up to $51 \%$ of companies indicated that such cooperation should not take. It is interesting to go back to the previous question, where $72 \%$ of respondents indicated that the source of their innovation is cooperation with other companies. As part of the explanation must be noted that the surveyed companies saying cooperation with other companies were there meant, among others, the ability to „copy" implemented by another company innovation or any kind of consultations on the implementation of the changes, as well as cooperation with companies which are clients of the respondents. Unfortunately, when it comes to equal cooperation with other organizations in the field of research and development answers are not satisfactory. Only $49 \%$ of respondents cooperates with other organizations in the field of $\mathrm{R}+\mathrm{D}$. The most significant, however, such cooperation is conducted with customers (78\% of responses) and suppliers ( $44 \%$ of responses). After $22 \%$ of respondents allocated to items such as cooperation with other national companies and other foreign companies. Details are presented in Chart 7. Here the sum of the percentages exceeds 100 (answers relate to only 49\% of respondents who declared that cooperate in research and development). 


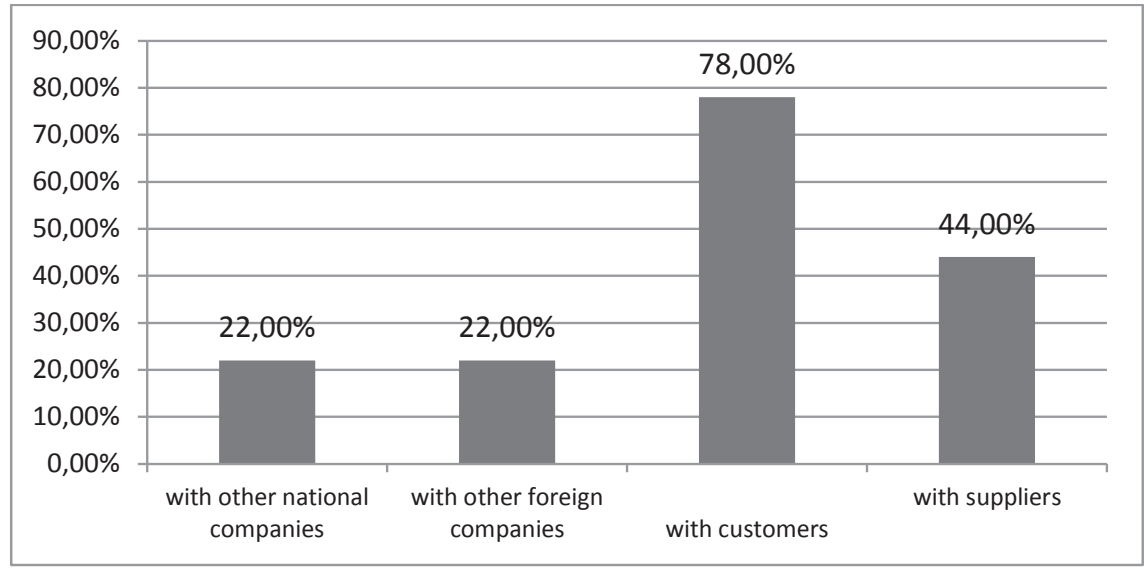

Chart 7. The cooperation of the surveyed enterprises in $\mathrm{R}+\mathrm{D}$

Source: own study based on the results of research in enterprise.

The above data requires a bit deeper analysis of the reasons for failing to cooperate with other entities in the field of research and development. As many as $51 \%$ of the surveyed firms such cooperation did not lead. Why? When asked about what is the greatest risk of cooperation in the field of research and development activities in accordance reply that most are afraid of theft of intellectual property, difficulties in management of personnel at a distance, as well as the loss of control over the process of innovation. Departing somewhat from the topic of cooperation with other organizations, look at the inside of the company. As mentioned at the beginning of publication the largest number of companies indicated that factor having the greatest impact on innovation of their companies is competent and creative managers. And what about in practice? Indeed, $89 \%$ of respondents believe that employees of their companies have the opportunity to present their ideas supervisor. What's more, 95\% believe that the implementation of these ideas will be taken into account in the company's strategy. This is a very impressive result, but you have to take into account the fact that the answers to the questions gave only managers, and not the employees themselves. It is to be hoped that the employees would respond in a similar manner.

Going forward, respondents were asked about how employees are motivated by their companies to submit their innovative ideas. 53\% creates a system of rewards for employees showing initiative in presenting their 
own ideas. After the $38 \%$ mentioned such answers as motivation by management and create a culture of entrepreneurial internal employees. Unfortunately, over $9 \%$ of respondents said that the company is not desirable initiative of workers in the field. Detailed data are presented in Chart 8.

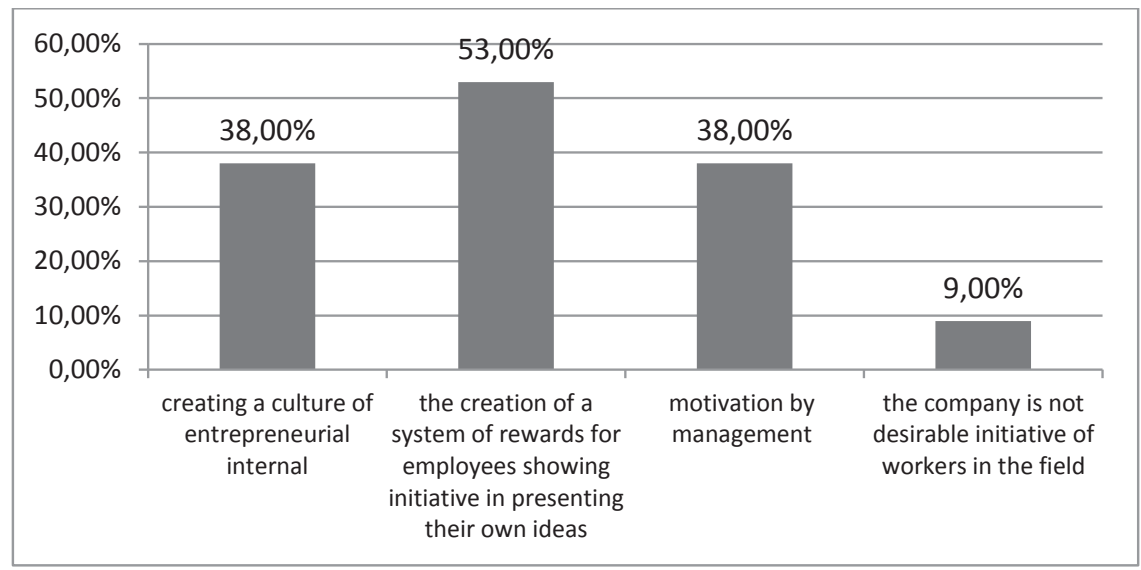

Chart 8. Ways to motivate employees to submit innovative ideas in the surveyed enterprises

Source: own study based on the results of research in enterprise.

The final aspect tackled in this publication are the barriers, which limit the daily activities of companies and even obstruct the path to change. The surveyed companies both agree that the biggest barrier to implementing innovation is simply a lack of funds, and the high costs associated with this implementation. Quite a significant problem becomes too high risk for the success of the innovation project and often simply lack of ideas for innovation.

\section{CONCLUSIONS}

Presented above empirical findings on the innovative activities of small and medium-sized companies of the kujawsko-pomorskie allow to draw several conclusions.

Firstly for more than $70 \%$ of the companies most important factor for innovative activities are competent and creative staff. Therefore, for them 
should create opportunities to present their innovative ideas and adequately motivate them to do so.

Secondly, the vast majority of respondents looking for sources of innovation through collaboration with other companies or through the initiative of its own employees.

Thirdly, only $49 \%$ of respondents cooperates with other actors in the field of research and development. Moreover, this cooperation is generally limited to the common actions in this area only with its customers or suppliers. The surveyed companies indicate that in cooperation in $\mathrm{R}+\mathrm{D}$ with other players most fear theft of intellectual property, difficulties in management of personnel at a distance, as well as the loss of control over the process of innovation.

Fourth, the surveyed companies say that the biggest barrier to implementing innovation is the lack of financial resources, as well as the high costs associated with this implementation. It is important also fairly high risk the success of the innovation project.

Details presented in this article the results of research points to the fact that small and medium-sized enterprises in kujawsko-pomorskie see a very great need for innovative economic activity. They realize how important this whole process is employed personnel. Top management is trying to not only motivate but also to appreciate and implement innovative ideas in the life of their employees. Unfortunately, the respondents are facing many barriers, which to a large extent limited or even discourage them from making any changes. Many of the smallest operators does not have its own research facilities and collaboration with other organizations in this field makes them a whole lot of anxiety and concern. Perhaps this is due simply to a lack of awareness of the benefits that come from this cooperation, and perhaps only because of the limited number of funds that could be suitable for this purpose. But be aware that small and medium-sized entities is the potential of the polish economy and, therefore, should be to create the conditions for the development of these entities, to be able to overcome barriers and problems that they face.

\section{LITERATURE}

Bogdanienko J. (2004), Innowacje jako czynnik przewagi konkurencyjnej, [w:] Bogdanienko J., Haffer M., Popławski W., Innowacyjność przedsiębiorstw, Wydawnictwo Uniwersytetu Mikołaja Kopernika w Toruniu, Toruń. 
Freeman Ch. (2008), Systems of Innovation, Edward Elgar, Cheltenham.

Glabiszewski W. (2008), Proinnowacyjna działalność przedsiębiorstw, [w:] M. Haffer, R. Haffer (red.), Aktywność innowacyjna małych i średnich przedsiębiorstw Pomorza i Kujaw, Wydawnictwo Uniwersytetu Mikołaja Kopernika w Toruniu, Toruń.

Grego-Planer D. (2014), Tajemniczy mistrzowie polskiej gospodarki-przeciętne firmy czy rynkowi liderzy?, „AUNC Zarządzanie”, nr 2, Toruń.

Grego-Planer D. (2014) Uwarunkowania zewnętrzne budowy potencjału konkurencyjnego tajemniczych mistrzów polskiej gospodarki, „AUNC Zarządzanie", nr 1, Toruń.

Haffer M. (2008), Działalność innowacyjna przedsiębiorstw, [w:] Haffer M., Haffer R. (red.), Aktywność innowacyjna małych i średnich przedsiębiorstw Pomorza i Kujaw, Wydawnictwo Uniwersytetu Mikołaja Kopernika w Toruniu, Torun.

Link A. N., Siegel D. S. (2007), Innovation, Enterpreneurship and Technological Change, Oxford University Press, Oxford.

Porter M. E. (2001), Porter o konkurencji, PWE, Warszawa.

Poznańska K. (2003), Innowacyjność jako źródło przewagi konkurencyjnej polskich przedsiębiorstw, „Centrum Wiedzy”, AIESEC Polska, Warszawa.

Simon H., Dietl M., (2009), Tajemniczy mistrzowie XXI wieku. Strategie sukcesu nieznanych liderów na światowych rynkach, Wydawnictwo Difin, Warszawa.

Stankiewicz M. J. (2002), Konkurencyjność przedsiębiorstwa. Budowanie konkurencyjności przedsiębiorstwa $w$ warunkach globalizacji, TNOiK - Dom Organizatora, Toruń.

Zmiany strukturalne grup podmiotów gospodarki narodowej w rejestrze Regon w województwie kujawsko-pomorskim w latach 2011-2012, Urząd Statystyczny w Bydgoszczy, Bydgoszcz 2013.

\section{CZYNNIKI, ŹRÓDŁA I MOTYWATORY INNOWACYJNOŚCI MAŁYCH I ŚREDNICH PRZEDSIĘBIORSTW WOJEWÓDZTWA KUJAWSKO-POMORSKIEGO}

Zarys treści: Innowacyjność, a zatem zdolność do wdrażania innowacji w obecnej dobie staje się, a przynajmniej powinna stać się atrybutem każdego przedsiębiorstwa. Jednakże samej innowacji nie należy postrzegać jedynie jako radykalną 
zmianę o znaczeniu międzynarodowym. Czasami nawet najdrobniejsze korekty w sposobie zarządzania czy metodzie produkcji okazują się niezwykle istotne w osiągnięciu przewagi konkurencyjnej na rynku. Otoczenie, w jakim funkcjonują podmioty gospodarcze, wymusza na nich bycie innowacyjnym bez względu na to, jaki mają zasięg swej działalności cz też rozmiar. Celem niniejszego artykułu jest zaprezentowanie wybranych aspektów innowacyjności sektora małych i średnich przedsiębiorstw województwa kujawsko-pomorskiego.

Słowa kluczowe: innowacyjność; badania i rozwój; małe i średnie przedsiębiorstwa. 